\title{
Forecasting Business Inventories AS AN ECONOMIC INDICATOR
}

\author{
Seyed-Mahmoud Aghazadeh \\ Department of Business Administration \\ State University of New York College At Fredonia \\ Fredonia, New York
}

Inventories, or business investment in stock, may be used as a major economic indicator. The movement in inventory reflects the changes in the volume of goods needed to support the changes in the rates of business operations. Consequently, inventories usually react closely to movements in orders, production, and sales.

Since the inventory investment component of aggregate demand fluctuates greatly over the course of actual cycles in the business world, it is extremely difficult to forecast the lcvel of inventories. This volatility can be attributed to excess stock held in case of a large increase in demand which in turn can cause an even greater change in inventory investment. This volatility can also be attributed to the lag between the change in sales and the desired response in inventory investment, along with numerous other factors that may shift in their impact on inventories and their level of importance. Evidence [6] suggests that, in general, inventories seem to lag behind business activity, and inventory shifts occur about three to six months after a turn has occurred in general business activity. Efforts to determine theoretical relationships in order to explain inventory investment have examined a wide range of influences ([2], [7], [8]), such as the costs of financing inventories, optimal costs (the cost of excess stocks contrasted with the cost of lost sales due inadequate inventories), and the state of capacity utilization and its implications for future supply flows. The major factor in all inventory theories, however, is the relationship to sales.

\section{Theoretical Framework and Applications}

The ultimate goal of economic forecasting ${ }^{1}$ in a business setting is to provide top management and line managers with expert advice about the present and future behavior of the economy, with special emphasis on how these developments are likely to impact the firms' business.

\footnotetext{
Journal of Business Strategies, Volume 5, Number 2 (Fall 1988)

${ }^{2}$ Two works which provide accessible treatments for the novice forecasters are: Dominick Salvatore, Theory and Problems of Statisties and Econometrics, New York, NY: McGraw-Hill (1982), and Robert S. Pindyck and Daniel L. Rubinfeld, Econometric Models and Economic Forecasts, New York, NY: McGraw-Hill (1976). A more advanced treatment, geared to forecasting, is Michael D. Intriligator, Econometric Models, Techniques and Applications, Englewood Cliffs, NJ: PrenticeHall (1978). A classical advanced treatment is J. Johnston, Econometric Methods, New York, NY: McGraw-Hill (1972).
} 
Forecasts of firm- and industry-specific variables such as costs, product demand, market share, resource requirements, and market demand conditions, are vital functions of a. business economic forecaster. This article translates the impact of these variables on sales, costs, and profitability of firm. The aim is to develop a set of simple equations for those sectors of the economy which are most sensitive to changing economic conditions, while basing the forecasts of other sectors on external factors and judgment.

The application of this model will be on the level of inventories as a group of indicators, while we develop the model based on step-by-step procedures.

In order to forecast business inventories based on sales, the types of inventories held by different businesses must be determined. These businesses, which include the stocks held by manufacturers, wholesalers, and retailers, are subject to different length lags between sales and changes in inventory investment. The problem comes from management's decisions in the firm to either increase, maintain, or reduce the level of inventory. These decisions are based on an expected future demand, price level, competition, and other internal decision-making factors. Therefore, if managers base their decisions on whatever current information they have, they may be caught in an unwanted position due to the time lags associated with investment inventory, and may need even greater corrective action to return to stabilization.

\section{Step 1}

\section{A: Forecast of Sales of Manufacturers}

The theoretical model that is used takes time lags and cyclical economic fluctuations into account. Retail sales, as an ongoing process, act as a determining factor manufacturer's and wholesaler's sales. This is because retail goods would have to be sold at an earlier time, either directly (by manufacturers) or indirectly (through wholesalers), to the retailers. The manufacturers' shipments are forecast using one month lagged total sales and the unemployment rate in the current month to detect any cyclical fluctuations. The estimating equation for manufacturers' shipments, using regression analysis from January 1975 to December 1985 (Bureau of the Census, U.S. Department of Commerce) is shown in logarithms as follows: ${ }^{2}$

$$
\ln M S_{t}=\ln A+B_{1} \ln T R S_{t-1}+B_{2} \ln U R_{t}
$$

where $M S_{t}=$ manufacturers' shipments in the current month, and $T R S_{t-1}=$ total retail sales in the prior month, and $U R_{t}=$ unemployment rate in the current month.

\footnotetext{
${ }^{2}$ Several studies that determine theoretical relationships to explain inventory investments are: Alan S. Blinder, "Retail Inventory Behavior and Business Fluctuations," Brookings' Papers on Economic Activity, No. 2, pp. 443-505 (1981); Michael A. Lovell, "Manufacturers' Inventories, Sales Expectations, and the Acceleration Principle," Econometrica (July 1961), pp. 293-314; Ruth P. Mack, Information, Expectations, and Inventory Fluctuations: A Study of Materials Stock an Hand and on Order, New York, NY: Columbia University Press for the National Bureau of Economic Research (1967).
} 


\begin{tabular}{|lr|}
\hline Coefficients & $t$ statistics \\
\hline $\ln A=4.92$ & $13.36^{a}$ \\
$B_{1}=-0.52$ & -0.61 \\
$B_{2}=-0.22$ & $-5.05^{a}$ \\
\hline$\rho=.99$ & $94.76^{a}$ \\
$\bar{R}^{2}=.91 \quad$ DW $=2.48$ & SER $=0.01$ \\
\hline
\end{tabular}

${ }^{a}$ Statistically significant at .01

According to these results, after the equation has been corrected for autocorrelation, manufacturers' shipments are negatively related to both lagged retail sales and the unemployment rate. The negative coefficient for the unemployment rate $\left(B_{2}\right)$ suggests, as expected, that the shipments are likely to decline when economic activity decreases. The coefficient $\left(B_{1}\right)$ suggests that for every $\$ 1$ increase in retail sales in the previous month, manufacturers' shipments decrease by $\$ .53$. This result was not expected, though the $t$ statistic for the coefficient $\left(B_{1}\right)$ is not significant. This result possibly stems from the fact that employment generates income which, in turn, is largely spent on consumer goods and services. Moreover, consumption fuels the economy not only because it directly comprises nearly two-thirds of total GNP, but also because it is the source of the derived demand for investment goods and for a large part of government services. Retail sales, in turn, comprise a major portion of personal consumption expenditure. Most purchases of durable and nondurable goods are made at retail outlets. Thus, since retail sales are a large portion of consumption, it follows that retail sales are also likely to be a function of personal income.

B. Forecast of Sales of Wholesalers

Since forecasts of manufacturers' shipments and retail sales are available, total sales by manufacturers, wholesalers, and retailers were forecast using the following equation:

$$
\ln (M S+W S+R S)_{t}=\ln A+B_{1} \ln P I_{t}+B_{2} \ln U R_{t}+B_{3} \ln T R S_{t-1}
$$

where $(M S+W S+R S)_{t}=$ total sales by manufacturers, wholesalers, and retailers, $P I_{t}=$ personal income, $U R_{t}=$ unemployment rate, and $T R S_{t-1}=$ total retail sales in the prior month

The results for equation (2) are shown below.

\begin{tabular}{|lr|}
\hline Coefficients & $t$ statistics \\
\hdashline $\ln A=3.3$ & $14.82^{a}$ \\
$B_{1}=0.29$ & $9.14^{a}$ \\
$B_{2}=-.17$ & $-5.92^{a}$ \\
$B_{3}=-.06$ & -0.97 \\
\hline$\rho=.90$ & $24.95^{a}$ \\
$\bar{R}^{2}=.99 \quad \mathrm{DW}=2.28$ & $\mathrm{SER}=.01$ \\
\hline
\end{tabular}

a Statistically significant at .01 
Except for the low insignificant coefficient for lagged retailed sales (corrected for autocorrelation), the results are as expected. Wholesalers' shipments can then be estimated as in equation $(3) .^{3}$

$$
\ln W S_{\mathrm{e}}=\ln \left(M S+W S+R S_{\mathrm{e}}\right)-\ln M S_{\mathrm{e}}-\ln T R S_{\mathrm{e}}
$$

The total retail sales $\left(\ln T R S_{e}\right)$ must be estimated before we can estimate the wholesalers' shipments ( $\ln W S_{\mathrm{e}}$ ) in equation (3).

A simple approach to forecasting retail sales can be performed, as in equation (4).

$$
\ln T R S_{t}=\ln A+B_{1} \ln P I_{t}+B_{2} \ln U R_{t}
$$

where $T R S_{t}=$ total retail sales, $P I_{t}=$ personal income, and $U R_{t}=$ unemployment rate.

It is logical that a forecast of retail sales estimates a relationship between retail sales and personal income. By this logic, an explanatory variable that is explicitly cyclical in nature should be included in the estimation of the more cyclical retail sales components. A choice for a cyclical variable would be the unemployment rate, which is hypothesized to have an inverse relationship to total retail sales.

The expected result of a regression analysis of the data for equation (4) is shown below:

\begin{tabular}{|lr|}
\hline Coefficients & $t$ statistics \\
\hline $\ln A=1.93$ & $(30.33)^{a}$ \\
$B_{1}=.28$ & $(30.82)^{\mathrm{a}}$ \\
$B_{2}=.14$ & $(-9.10)^{a}$ \\
\hline$\rho=.88$ & $(22.71)^{a}$ \\
$\bar{R}^{2}=.89 \quad$ DW $=2.01$ & $\mathrm{SER}=.03$ \\
\hline
\end{tabular}

${ }^{a}$ Statistically significant at .01

\section{Step 2}

Forecast of Inventory/Sales Ratio

The moving average can control the changes in inventory/sales ratios over time and utilizes the most recent data in order to keep the forecast responsive. ${ }^{4}$ The result can be improved by doing a regression of the actual inventory/sales ratio to its moving average, as in the following equation:

$$
\ln \frac{I}{S}=\ln A+B_{1} \ln M A I S
$$

${ }^{3}$ Equation (3) is the logarithm form of the following equation:

$$
W S_{e}=\left(M S+W S+R S_{e}\right)-M S_{e}-T R S_{e}
$$

where the estimated values for manufacturers' shipments and retail sales are subtracted from the estimated levels for the total sales.

${ }^{4}$ The inventory/sales ratios for each sector can be derived based on the past trends. A twelvemonth moving average of actual inventory/sales ratios may be constructed for 1984 , using the 
Using equation (5), regression results for manufacturing, wholesale, and retail are shown below.

\begin{tabular}{|c|c|}
\hline \multicolumn{2}{|c|}{ Manufacturing } \\
\hline Coefficients & $t$ statistics \\
\hline $\ln A=4.60$ & -1.12 \\
\hline$B_{1}=.97$ & $6.62^{\circ}$ \\
\hline$\rho=.88$ & $15.41^{\circ}$ \\
\hline $\bar{R}^{2}=.97 \quad \mathrm{D}$ & $\mathrm{SER}=.01$ \\
\hline
\end{tabular}

\begin{tabular}{|c|c|c|c|}
\hline \multicolumn{2}{|c|}{ Wholesale } & \multicolumn{2}{|l|}{ Retail } \\
\hline Coefficients & $t$ statistics & Coefficients & $t$ statistics \\
\hline $\ln A=.05$ & .08 & $\ln A=.01$ & .89 \\
\hline$B_{1}=.94$ & $6.05^{\circ}$ & $B_{1}=.99$ & $5.41^{a}$ \\
\hline$\rho=.84$ & 18.69 & $\rho=.80$ & $23.20^{\circ}$ \\
\hline $\mathrm{DW}=2.20$ & $\mathrm{SER}=.03$ & $\mathrm{DW}=1.85$ & $\mathrm{SER}=.09$ \\
\hline
\end{tabular}

The results are expected. The $\ddot{R}^{2}$ is high for all equations, suggesting that the large amount of variation in inventory/sales ratios is explained by the variation in the change in moving average of inventory/sales ratios for all equations.

\section{Applications}

Recent sales and production trends may provide a basis for refining forecast of the change in inventory levels of a company. Inventory adjustment, because it aids the distribution and production of final goods, might be viewed as investment-type activity, in contrast to the consumption oriented activities. In addition, reports of the National Association of Purchasing Managers on the current status of sales, orders and inventories, supply helpful information about the intentions of business to invest in inventories.

As was illustrated, the inventory forecast was obtained based on the product of forecast sales level by the forecast inventory/sales ratio. Since these forecasts are built following equation:

$$
\text { MAIS }-\frac{1}{12} \times \sum_{t=1}^{12}\left(\frac{I}{S}\right)_{t}
$$

where $M A I S=$ moving average of inventory/sales tatio and $\frac{I}{S}=$ inventory $/$ sales ratios.

A good introduction to the nature and main aspects of the Autoregressive Integrated Moving Average (ARIMA) method is provided in C.W.J. Granger, Forecasting in Business and Economics, New York, NY: Academic Press (1980), Ch. 3, p. 64. The original source on this technique is G.E.P. Box and G.M. Jenkins, Time Series Analysis, San Francisco, CA: Holden-Day (1970). A more simplified version of the technique is provided by C. Nelson, Applied Time Series Analysis, San Francisco, CA: Holden-Day (1973). 
upon one another-due to their theoretical relationships-their consistency is assured. Underlying this approach is the basic concept that these forecasts are interrelated. Although the forecast relationships constituted a model of macroeconomic activity, an indicative forecast model of microeconomic processes, based on the same logical relationships, could be developed and used to anticipate future turning points.

Moreover, this approach is not very costly. There are only a few regression equations to be computed which need only be updated annually; forecast updates may be computed manually, or at little more cost but at much greater speed, using a microcomputer. The advantage of a macroeconomic model is that forecasts of overall macroeconomic conditions constitute the most expert contribution the forecaster makes to a firm's planning and general business operations. Managers may have more detailed knowledge of firm-specified topics-such as product market conditions, capacity, and production methods-but the performance of the overall economy is where the economist's predictive knowledge is greater. Alternatively, specific macroeconomic measures often are key inputs to the firms's own planning.

\section{Summary}

Change in the level of inventories is one of the most important classes of economic indicators. The change in inventories results from several factors, such as sales, production, and the intended inventory/sales ratio. The present paper developed a forecasting model based on the fact that an explicit forecast linkage does exist among the variables. This information was used to modify not just the subsequent forecasts of retail sales, but also those for the other variables as well. Inventory/sales ratios for manufacturers, wholesalers, and retailers were forecast, and finally, the inventory forecast was obtained.

The model described here was used to illustrate an approach to inventory forecasting. Using a few simply derived, exogenous variables the forecaster is able to build a simple yet detailed forecast model for inventory. The model is more useful than the single-equation reduced form which is commonly employed because it allows the forecaster to draw conclusions about not only inventory but also its dynamic components.

\section{References}

1. Bales, Dale G. and Larry C. Peppers. Business Fluctuations: Forecasting Techniques and Applications. Englewood Cliffs, N.J: Prentice-Hall (1982).

2. Blinder, Alan S. "Retail Inventory Behavior and Business Fluctuations." Brookings Papers on Economic Activity, No. 2 (1981), pp. 443-505.

3. Bureau of Economic Analysis. U. S. Department of Commerce.

4. Bureau of Labor Statistics. U. S. Department of Labor.

5. Bureau of the Census. U. S. Department of Commerce. 
6. Butler, William F., Robert A. Kavesh, and Robert B. Plalatt. Methods and Techniques of Business Forecasting. Part three ("Inventories"), Louis J. Paradiso. Englewood Cliffs, NJ: Prentice-Hall (1974).

7. Lovell, Michael A. "Manufacturers' Inventories, Sales Expectations, and the Acceleration Principle." Econometrica. (July 1961), pp. 293-314.

8. Mack, Ruth P. "Information, Expectations, and Inventory Fluctuations: A Study of Materials Stock on Hand and on Order." New York, NY: Columbia University Press for the National Bureau of Economic Research (1967).

9. McAuley, John J. Economic Forecasting for Business: Concepts and Applications. Englewood Cliffs, NJ: Prentice-Hall (1986).

10. Matzler, Lloyd A. "The Nature and Stability of Inventory Cycles." Review of Economics and Statistics, Vol. 3 (August 1941), pp. 113-29.

11. Mills, Edwin S. "The Theory of inventory Decisions." Econometrica, Vol. 25 (April 1957), pp. 222-39.

12. Whitman, Marina von Neuman. "Economics from Three Perspectives." Business Economics (January 1983), pp. 20-24. 